Egyptian J. Anim. Prod.(1994) 31(1):137-147.

\title{
OVULATION RATE AND REPRODUCTIVE PERFORMANCE OF OSSIMI, AWASSI, CHIOS SHEEP AND THEIR CROSSES
}

\author{
M.T. Mousa', M.M. Shetaewi ${ }^{2}$ and E. Shehata
}

1) Animal production Research Institute, Ministry of Agriculture, Cairo, Egypt 2) Department of Animal Production, Faculty of Environment Agricultural Science in El-Arish, University of Suze Canal, North sinai, Egypt

\section{SUMMARY}

This study included a total of 111 ewes of five breeds i.e. Ossimi (O), Awassi (A), Chios (C), and their crosses ( $\mathrm{CxO}$ and $\mathrm{CxA}$ ). To obtain ovulation rates, laparoscopy was performed on ewes that exhibited estrus and were mated with fertile rams (83 ewes). Ewes were two to three years old and weighed between 37 and $42 \mathrm{~kg}$ at test. Reproductive ability of ewes and lamb performance up to weaning were evaluated. Ovulation rate was higher $(\mathrm{P}<0.05)$ in Chios ewes $(2.0$ corpora lutea/ ewe) than Awassi (1.22), Ossimi (1.47) and CxA (1.39), but chios did not differ from $\mathrm{C} \times \mathrm{O}(1.72)$. Litter size did not differ significantly among breed groups $(\mathrm{P}<0.01)$, but tended to be higher in Chios and $\mathrm{C} x \mathrm{O}$ compared with the other breeds. A significant positive correlation was found between number of corpora lutea and number of lamps born $(=+0.55), \mathrm{P}<0.01)$. Weight of lambs born per ewe lambed didn't differ significantly among breed groups $(P<0.10)$ but $C \times 0$ ewes tended to give higher kilograms of lambs at birth $(4.72 \mathrm{~kg} \mathrm{lamb} /$ ewe) followed by chios (4.51) compared with ossimi (4.10), Awassi (4.05) and $\mathrm{C} \times \mathrm{A}(4.0)$. At weaning, lambs of $\mathrm{C} \times \mathrm{O}$ were heavier $(\mathrm{P}<0.05)$ than those of the other breed groups. Number of lambs weaned per ewe lambed did not differ significantly among breeds, but total weight

Lsisued by Egyptian Society of Animal Production. 
of lambs weaned was significantly greater in $\mathrm{C} \times \mathrm{O}$ ewes.

Keywords: Sheep, reproduction, laparoscopy, crossing, lambs

\section{INTRODUCTION}

Most of the variation in prolificacy among breeds and within breeds is attributed to corresponding differences in ovulation rate (Hanrahan, 1985). Data on ovulation rates in Awassi, ossimi, and their crosses with Chios are scarce. The objectives of this study were to determine ovulation rates and productivity of crossbred ewes as compared to purebred ewes under conditions prevailing in the subtropical environment of Middle Egypt.

\section{MATERIALS AND METHODS}

This study was carried out at Mallawi Research station (a subtropical zone around $27^{\circ} 30-\mathrm{N}$ ), belonging to Animal Production Research Institute. Awassi and local Ossimi ewes were mated to Chios rams to produce $F 1$ crossbred lambs. In May 1991, the purebred Ossimi (O). Awassi (A) and Chios (C), together with crossbred ewes ( $\mathrm{C} x \mathrm{O}$ and $\mathrm{Cx} A$ ) were grouped into four mating groups of 20-26 ewes each and were run with $O, A, C, O$ and $A$ fertile rams, respectively. Mating period lasted for 40 days. Laparoscopy was performed on a total of 83 ewes that exhibited estrus and were mated with fertile rams, to obtain ovulation rate (Roberts,1968). These ewes included $15,18,14,18$ and 18 of $\mathrm{O}, \mathrm{A}, \mathrm{C},(\mathrm{C} \times \mathrm{X})$ and $(\mathrm{C} \times$ A) breed groups, respectively. Number of corpora lutea on each ovary was recorded to denote ovulation rate.

All ewes were grazing on Egyptian Clover (Trifolium alexandrium) beginning December 1990 till breeding season began in May 1991. Then, they grazed crop residues available at that time (either wheat or bean) besides the green fodder. In addition, ewes were supplemented with pelleted concentrate mixture starting with $0.5 \mathrm{~kg} /$ ewe, increasing to $1 \mathrm{~kg} /$ ewe during late pregnancy and lactation. Mineralized salt blocks were available to all ewes. Ewes were subjected to the routine vaccination program against infectious diseases and also injected or drenched against internal parasites.

Body weights of ewes at mating and parturition as well as sex and type of birth for lambs within $12 \mathrm{~h}$ following 
parturition were recorded. Number and weight of lambs weaned were also obtained.

Data were analyzed using the General Linear Model (GLM) procedure of the Statistical Analysis system for personal computers (SAS, 1987). Body weight of ewes at mating, weight of lambs born per ewe lambed (total birth weight), weight of lambs weaned per ewe lambed (total weaning weight) were analyzed by one-way analysis of variance. Gestation length, birth weight and weaning weight of lambs were analyzed as a five (breed group) $x$ two (type of birth) factorial arrangement within a completely randomized design (Steel and Torrie, 1980). ovulation rate (no.of corpora lutea per ewe), litter size (no. of lambs born per ewe lambed), and no. of lambs weaned per ewe lambed were analyzed by Chi-square procedure for categorical data (SAS, 1987).

\section{RESULTS}

Mean body weight ewes at mating for various breed groups of ewes are shown in Table 1. Awassi ewes were significantly lighter $(37.2 \mathrm{~kg}, \mathrm{P}<0.05)$ than all other breed groups. Ossimi ewes exhibited the highest mean body weigh $(42.1 \mathrm{~kg})$, whereas chios and its crosses were almost similar $(40.2$ to $40.7 \mathrm{~kg})$. Gestation length averaged $148.5 \pm 0.2 \mathrm{~d}(\mathrm{n}=83)$ in all breed groups combined (Table 1); an interaction between breed groups and gestation length of ewes carrying twins did not differ ( $P>0.10)$ among breed groups, whereas that of ewes carrying singles were significantly different $(P<0.05)$. Chios $x$ ossimi breed group had the longest gestation period ( 150.5 d) among all of those carrying single lambs.

Table 1. Least squares meanst S.E of body weight ( $\mathrm{Kg}$ ) of ewes at mating, gestation length an conception

\begin{tabular}{|c|c|c|c|c|c|}
\hline \multirow{3}{*}{$\begin{array}{l}\text { Breed } \\
\text { group } \\
\text { Ossimi }(0)\end{array}$} & \multirow{2}{*}{$\begin{array}{l}\text { No } \\
\text { ewes } \\
\text { Joined } \\
\text { with rams }\end{array}$} & \multirow{2}{*}{$\begin{array}{l}\text { Body weight* } \\
\text { at mating }\end{array}$} & \multirow{2}{*}{$\begin{array}{r}\mathrm{CR} \\
\%\end{array}$} & \multicolumn{2}{|c|}{ Gestatation Length (days)* } \\
\hline & & & & $\begin{array}{l}\text { Ewes haveing } \\
\text { single lambs }\end{array}$ & $\begin{array}{l}\text { Ewes having } \\
\text { twin lambs }\end{array}$ \\
\hline & 20 & $42.1^{2} \pm .8$ & 75 & $146.4^{4} \pm .7(12)$ & $151.7 \pm 1.1(3)$ \\
\hline Awassi (A) & 26 & $37.2^{h} \pm .7$ & 69 & $147.6^{30} \pm .6(14)$ & $148.8 \pm .9(4)$ \\
\hline Chios (C) & 20 & $40.7^{3} \pm .8$ & 70 & $147.4^{11} \pm .8(8)$ & $150.0 \pm .7(6)$ \\
\hline$C \times 0$ & 22 & $40.2^{a} \pm .7$ & 82 & $150.5^{b} \pm .7(11)$ & $148.9 \pm .7(7)$ \\
\hline $\mathrm{C} \times \mathrm{A}$ & 23 & $40.3^{3} \pm .7$ & 78 & $148.2^{\circ} \pm .6(15)$ & $150.0 \pm 1.6(3)$ \\
\hline
\end{tabular}

*Means in the same column not having a common Superscript differ significantly 
Ovulation rate (Table 2 ) was higher $(\mathrm{P}<0.05)$ in Chios ewes ( $2.0 \mathrm{C} . \mathrm{L} /$ ewe) than Awassi (1.22), Ossimi (1.47) and $C \times A(1.39)$ but did not differ from $C \times O$ (1.72). Litter size (Table 2) did not differ significantly ( $P>0.10)$ among breed groups, but tended to be greater in Chios ( 1.43 lambs/ewe) and $C \times O$ ( 1.39 lambs/ewe) compared with other breed groups. A significant positive correlation was found between number of corpora lutea and number of lambs born $(r=+0.55, \mathrm{P}<0.01)$.

Table 2. Least squares means of lambing rates, ova wastage and total weight of lambs born per ewe lambed in various breed groups

\begin{tabular}{|c|c|c|c|c|c|c|c|}
\hline $\begin{array}{l}\text { Breed } \\
\text { group }\end{array}$ & $\begin{array}{l}\text { No. } \\
\text { ewes }\end{array}$ & $\begin{array}{l}\text { ovulation } \\
\text { rate }(C L) \text { ewe }\end{array}$ & $\begin{array}{l}\text { No. } \\
\text { lambs }\end{array}$ & Lambs & born per & $\begin{array}{c}\text { Ovum } \\
\text { wastage }\end{array}$ & $\begin{array}{l}\mathrm{kg} \text { lams } \\
\text { born per }\end{array}$ \\
\hline & lambed & & born & $\begin{array}{l}\text { ewe } \\
\text { Joined }\end{array}$ & $\begin{array}{l}\text { ewe } \\
\text { lambed }\end{array}$ & $\%$ & ewe lambe \\
\hline Ossimi(0) & 15 & $1.47^{x x} \pm 0.15$ & 18 & 0.90 & $1.20 \pm 0.41$ & 18 & $4.10 \pm 0$. \\
\hline Awassi(A) & 18 & $1.22^{C} \pm 0.13$ & 22 & 0.85 & $1.22 \pm 0.43$ & 0 & $1.05 \pm 0$. \\
\hline Chios(C) & 14 & $2.00^{a} \pm 0.15$ & 20 & 1.00 & $1.43 \pm 0.51$ & 29 & $4.51 \pm 0$. \\
\hline$C \times 0$ & 18 & $1.72^{a b} \pm 0.13$ & 25 & 1.14 & $1.39 \pm 0.50$ & 19 & $4.72 \pm 0$. \\
\hline$C \times A$ & 18 & $1.39^{6 x} \pm 0.13$ & 21 & 0.91 & $1.17 \pm 0.38$ & 16 & $4.00 \pm 0.7$ \\
\hline
\end{tabular}

Means in the same column not having common superscript differ significantly $(P<0.05)$

Weight of lambs born per ewe lambed did not differ significantly among breed groups (Table 2). However, $\mathrm{C} \times \mathrm{O}$ ewes tended to give maximum kilograms of lamb at birth (4.72 kg lambs/ewe) followed by Chios (4.51) compared with Ossimi (4.10), Awassi (4.05) and C x A (4.0).

Birth weight means of lambs are presented in Table 3. In general, single lambs in all breed groups were heavier than twin lambs except in Awassi where twins showed a slightly higher mean $(3.38$ vs $3.26 \mathrm{~kg})$. An interaction between breed of ewe and type of birth was noted. Birth weight of single lambs differed significantly $(\mathrm{P}<0.05)$ among breed groups. As shown in Table 3, single lambs of Awassi and Chios had almost similar weights $(3.26$ and $3.31 \mathrm{~kg})$, but were lighter than those of the Ossimi and chios crosses. On the other hand, no significant differences were noted among twins of all breeds, although Awassi twins were apparently heavier than those of all breed groups. 
Lamb losses between birth and weaning were significantly greater $(15 \%, \mathrm{p}<0.06)$ for Chios ewes than $C \mathrm{X} A$ ewes; other differences were not significant (Table 4). Lamb survival to weaning ranged from $85 \%$ in chios group to $100 \%$ in $\mathrm{C} \times \mathrm{A}$ group.

Table 3. Least-squares means of birth weight for lambs of various ewe breed groups

\begin{tabular}{|c|c|c|c|c|c|}
\hline & & \multicolumn{4}{|c|}{ Breed group } \\
\hline & Ossimi (0) & Awassi(A) & Chios(C) & $6 \times 0$ & $C \times A$ \\
\hline & $\bar{T}$ & $\bar{T}$ & $\bar{T}$ & $\bar{\top}$ & s \\
\hline Breed x Type & $3.62^{120} 3.02$ & $3.26^{\circ} 3.38$ & $3.31^{\infty} 3.05$ & $3.80^{2} \quad 3.08$ & $3.56^{\text {ac }} 3.10$ \\
\hline MeantS.E. & $3.32 \pm 0.13$ & $3.32 \pm 0.11$ & $3.18 \pm 0.12$ & $3.44 \pm 0.10$ & $3.33 \pm 0.13$ \\
\hline
\end{tabular}

$S=$ single lamb born, $T=$ Twin lamb born

Means of single lambs not having a common superscript differ significantly $(P<0.05)$; other

Means not having superscripts did not differ significantly $(P<0.05)$.

Table 4. Postnatal lamb survival in various breed groups

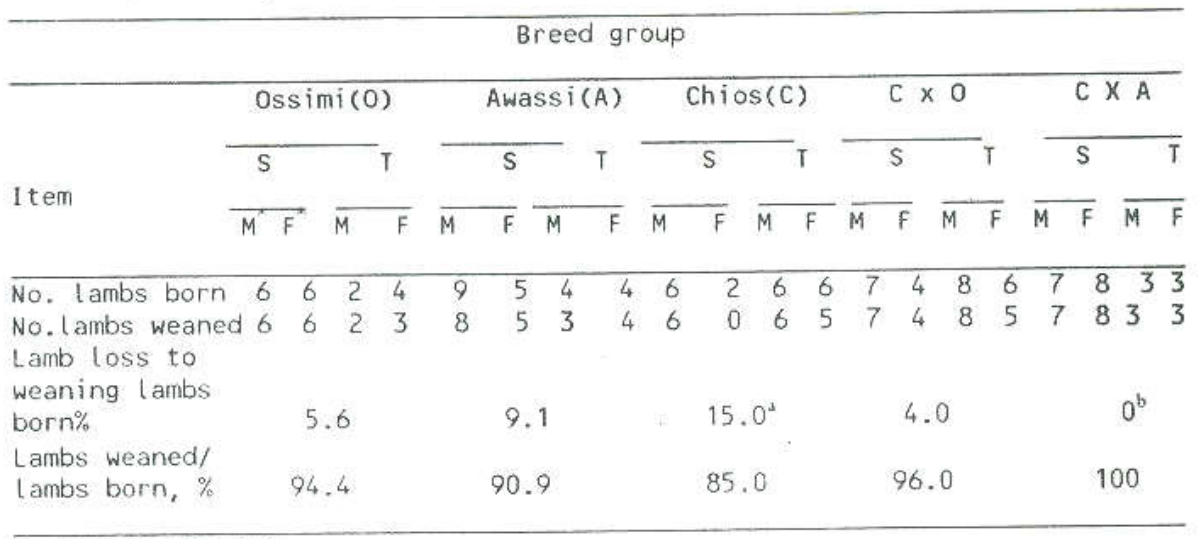

$S=$ Single, $T=$ Twin.

$M=$ male, $F=$ female.

$a, b<(P<.06)$.

At weaning single lambs were heavier $(\mathrm{P}<0.01)$ than twin lambs in all breed groups (Table 5). Lambs of $\mathrm{C} x \mathrm{O}$ achieved the highest $(\mathrm{P}<0.05)$ mean, and no interaction between breed and type of birth was noted for weaning weight.

overall productivity measured as number of lambs 
weaned per ewe lambed did not differ significantly among breed groups; but when measured as number of $\mathrm{Kg}$ lambs weaned per ewe lambed, significant differences were detected. The $\mathrm{C} \times \mathrm{O}$ crossbred ewes had the highest mean (17.8 $\mathrm{kg} /$ ewe) followed by $\mathrm{C} \times \mathrm{A}(15.4 \mathrm{Kg} /$ ewe), whereas Awassi ewes had the lowest mean $(13.9 \mathrm{Kg} / \mathrm{ewe})$.

Table 5. Overall productivity of various breed groups of ewes expressed as total number and total weight of lambs weaned per ewe lambed

\begin{tabular}{|c|c|c|c|c|c|}
\hline $\begin{array}{l}\text { Breed } \\
\text { group }\end{array}$ & $\begin{array}{l}\text { No. } \\
\text { ewes } \\
\text { lambed }\end{array}$ & $\begin{array}{l}\text { No. } \\
\text { lambs } \\
\text { weaned }\end{array}$ & $\begin{array}{l}\text { No. lambs } \\
\text { weaned per } \\
\text { ewe lambed } \\
\text { LS Means SE }\end{array}$ & $\begin{array}{l}\text { Weaning } \\
\text { wt. } \\
\text { (Kg) }\end{array}$ & $\begin{array}{l}\text { Kg lambs" } \\
\text { weaned per } \\
\text { ewe lambed } \\
\text { LS Mean SE }\end{array}$ \\
\hline Ossimi(0) & 15 & 17 & $1.13 \pm 0.13$ & $12.32 \pm 0.30^{\circ}$ & $14.5^{b c} \pm 1.3$ \\
\hline Awassi (A) & 18 & 20 & $1.11 \pm 0.11$ & $12.18 \pm 0.27^{a}$ & $13.9^{b} \pm 1.2$ \\
\hline Chios (C) & 14 & 17 & $1.21 \pm 0.13$ & $12.60 \pm 0.29^{\mathrm{a}}$ & $14.9^{b x} \pm 1.4$ \\
\hline$c \times 0$ & 18 & 24 & $1.33 \pm 0.11$ & $13.45 \pm 0.23^{b}$ & $17.8^{\circ} \pm 1.2$ \\
\hline$C \times A$ & 18 & 21 & $1.17 \pm 0.11$ & $12.77 \pm 0.28^{\mathrm{a}}$ & $15.4^{k x} \pm 1.2$ \\
\hline
\end{tabular}

Mean not having a common superscript differ significantly $(P<005)$.

\section{DISCUSSION}

Differences between breeds in gestation period could be explained through differences in weight of their lambs at birth. The greater number of days a lamb stays in uterus (within narrow limits), the heavier it possibly will be at birth. Therefore, the extended gestation period of $C \times O$ ewes (Table 1 ) could be related the greatex birth weight of their of lambs (Table 3). The finding that no differences in gestation length among ewes carrying twins in the present study could be due to the small number of ewes which consequently increased the standard error of the means. Mabrouk et al. (1976) reported a highly significant relationship between gestation period and birth weight of the lambs in Barki, Merino, Awassi and their crosses. Kishore et al. (1980) reported a significant correlation of 0.25 between birth weight and gestation period. On the other hand, shetaewi (1988) found no relationship between lamb birth weight and gestation length of the dam in Rambouillet ewes.

The superiority of chios ewes in ovulation rate 
(Table 2) was reflected in a higher litter size (Table 4) compared to other breed groups. In this respect, Meyer and clark (1982) reported that differences in litter size at birth were attributed to genetic differences in ovulation rate.

Mavrogenis (1985) reported that Chios ewes showed a clear superiority in number of lambs born per ewe lambed (1.69, $\mathrm{P}<0.01$ ) over Awassi, Chios-Awassi and AwassiChios (1.07, 1.17 and 1.28 , respectively). Aboul-Naga (1985) found that Finn crossbred ewes excelled those of the local pure-bred ewes (Rahmani and Ossimi) in litter size. In the present study, $c x$ o crossbred leave an intermediate litter size mean (1.39) between Chios (1.43) and Ossimi (1.20), which can be attributed to the effect of heterosis. Valls ortiz (1983) found that Romanov-Aragon crosses produced $40 \%$ more lambs per ewe than Aragon purebreds whereas Hohenboken et al. (1976) and Shrestha et al. (1983) indicated that the effect of heterosis on litter size was small ( 1.8 to $1.6 \%$ ) and not significant. Thomas and Whiteman (1979) showed that the relative contribution of different breeds to crossbred groups of ewes resulted in a significant change in some cases and none in others.

The relative increase in lamb survival in crossbred groups (Table 4) could be attributed to the effect of heterosis on birth weight of lambs and their intake of colostrum and milk. Khalaf (1979a\&b) reported that litter size, lamb birth weight and colostrum intake by the lamb had important effects on perinatal lamb mortality.

The overall productivity expressed as number of lambs weaned per ewe lambed ranged from 1.33 in $\mathrm{c} x \mathrm{O}$ to 1.11 in Awassi (Table 5) and the overall average was $1.19 \pm$ 0.05 . Zahed (1988) reviewed overall reproductive ability in many foreign and local breeds and crosses of sheep and found that it ranged from 0.062 to 2.44 when expressed as number of lambs weaned per ewe lambed. In his study on Rahmani, Barki and ossimi local breeds as well as those resulting from crossing ewes of those local breeds with Finnish Landrace and Ile-de-France rams, he found that number of lambs weaned per ewe lambed was significantly influenced by type of mating i.e. purebred or crossbred. In the present study, no significant differences in the number of lambs born per ewe lambed were noted among breed groups of ewes, 
although $\mathrm{C} x$ o weaned more lambs per ewe compared to other breed groups (Table 5).

The effect of heterosis appeared clearly when reproductive ability was expressed as total weight (Kg) of lambs weaned per ewe lambed. As shown in Table 5 , $C \times O$ weaned heavier offspring than $C \times A$; both of them weaned heaviex offspring than purebred ewes. The reason that $\mathrm{C} \times \mathrm{O}$ performed better than $\mathrm{C} \times \mathrm{A}$ can be attributed to the effect of ossimi genes in the crossbred ewes. The ossimi purebred ewes in the present study were somewhat better than Awassi purebred ewes probably because the Awassi ewes flock involved in the present study had long been inbred. However, this finding confirms earlier results of Aboul-Naga (1978) who reported that both Ossimi and suffolk-Ossimi ewes weaned more $(P<0.05)$ lambs per ewe lambed than suffolk ewes.

In conclusion, the highest rate of ovulation was recorded for chios ewes. Litter size of these ewes was consequently larger compared to other breed groups. Therefore, to achieve a given increase in litter size, selection for ovulation rate is better than selection for litter size, because ovulation rate sets the upper limit for litter size. The $C \times 0$ crossbred was next to chios ewes in both ovulation rate and litter size. However, the crossbred surpassed the chios purebred in $\mathrm{Kg}$ lambs born per ewe lambed and in number and weight of lambs weaned per ewe lambed due to the effect of hybrid vigor. These results indicate a good possibility to get benefit from this cross for crossbred lamb production from local ossimi.

\section{REFERENCES}

$$
\begin{aligned}
& \text { Aboul-Naga, A. M., 1978. Using Suffolk sheep for } \\
& \text { improving lamb production from subtropical } \\
& \text { Egyptian sheep. I- Reproductive performance. J. } \\
& \text { Agr. Sci. Camb. } 90: 125 \text {. } \\
& \text { Aboul-Naga, A. M., } 1985 \text {. Crossbreeding for fecundity in } \\
& \text { subtropical sheep. In: R. Land and D. Robinson } \\
& \text { (Ed.). Genetics of Reproduction in Sheep. pp } 55- \\
& \text { 62. Butterworth, London } \\
& \text { Hanrahan, J. P. } 1985 \text { Genetics varlatiol . ovulation } \\
& \text { rate in sheep In. R. Land and D Rc. inson (Ed, } \\
& \text { Genetics of Reproduct.on in Sheef pp } 37-46 \\
& \text { Butterworth Londor }
\end{aligned}
$$


Hohenboken, W., K. Corum and R. Bogart, 1976. Genetic, environmental and interaction effects in sheep. IReproduction and lamb production per ewe. J. Anim. Sci., 42:299.

Khalaf, A. M., D. L. Doxey and J. T. Baxter, 1979a. Late pregnancy ewe feeding and lamb performance in early life. I- Pregnancy feeding levels and perinatal lamb mortality. Anim. Prod. 29:393.

Khalaf, A. M., D. L. Doxey and J. T. Baxter, 1979b. Late pregnancy ewe feeding and lamb performance in early life. II- Factors associated with perinatal lamb mortality. Anim. Prod. 29:401.

Kishore, K., D. Gour, R. S. Rawat, and G. L. Arora, 1980. A note on gestation length in crossbred sheep. Ind. J. Anim. Sci. 50:565.

Mabrouk, M. M., E. S. E. Galal, Y. S. Ghanem and H. A. El-okash, 1976. A study of some reproductive aspects in sheep under semi-arid conditions. Egypt. J. Anim. prod. 16:1.

Mavxogenis, A.P., 1985. The fecundity of Chios sheep. In: R. Land and D. Robinson (Ed.). Genetics of Reproduction in sheep. pp 63-67. Butterworth, London.

Meyer, H, H. and J. N. Clark, 1982. Effect of ewe ovulation rate and uterine efficiency on breed and strain variation in litter size. Proceedings of the New Zealand Society of Animal Production $42: 33-35$. A. B. A. 51:no. 2231 .

Roberts, E.M., 1968. Endoscopy of the reproductive tract of the ewe. Proceedings of the Australian society of Animal production. 7:192.

SAS., 1987. SAS/STAT Guide for Personal computers (Version 6 ED.). SAS Inst., Inc., Cary, N. C.

Shetaewi, M.M., 1988. Effect of concentrate and lasalocid supplementation during late pregnancy and lactation on productivity, wool follicle development, blood chemistry and hormone profiles of Rambouillet sheep. pp 54-73, Ph. D. Dissertation. New Mexico state University, Las Cruces, NM, USA.

Shrestha, J.N.B., W.E. Rempel, W.J. Boylan and K.P. Miller, 1983. General, specific, maternal and reciprocal effects for ewe productivity in crossing five breeds of sheep. Can. J. Anim. Sci. $63: 497$. 
Steel, R. G. D. and J.H. Torrie, 1980. Principles and Procedures of Statistics: A Biometrical Approach (2nd Ed.). McGraw-Hill Book Co., New York.

Thomas, D. L. and J. V. Whiteman, 1979. Effects of substituting Finn-sheep and Dorset breeding for Rambouillet breeding. I- Productivity of young, spring-lambing ewes. J. Anim. Sci., 48:256.

Valls ortiz, M., 1983. Frequent lambing of sheep flocks in spain; productivity and management consequences. Lives. Prod. Sci. 10:49 (Cited by Zahed, S. M. 1988).

Zahed, S. M., 1988. The reproductive performance of some local breeds of sheep and their crosses with foreign breeds. M.Sc. Thesis. Faculty of Agr., AlAzhar University, Cairo,Egypt. 


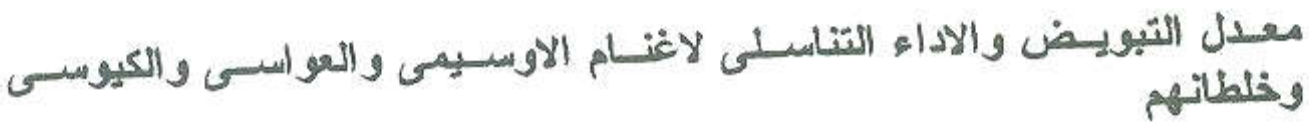

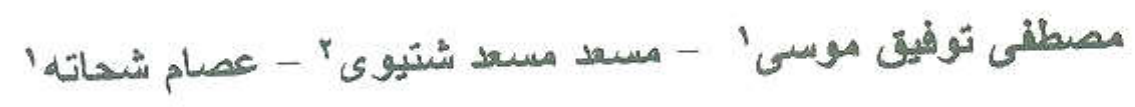

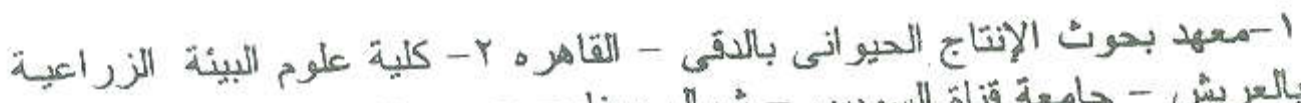

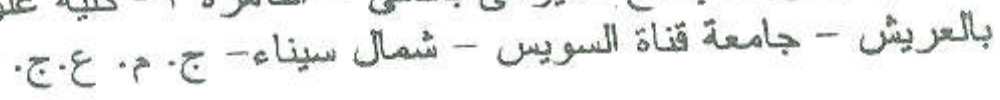

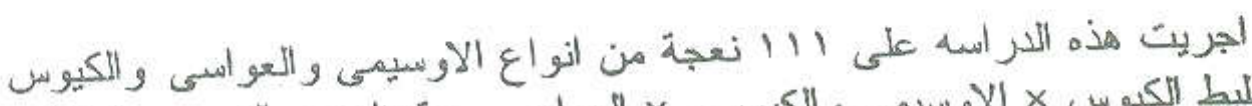

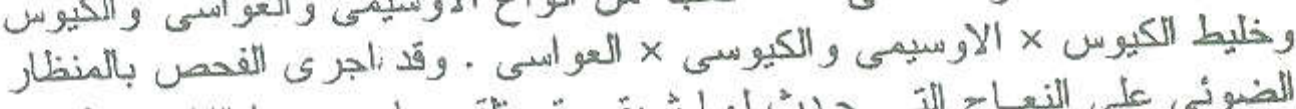

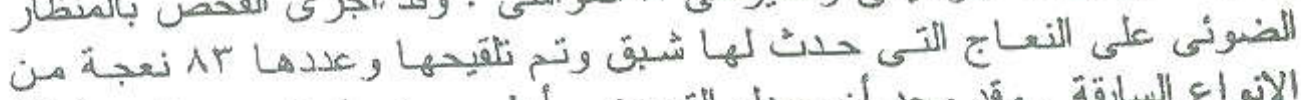

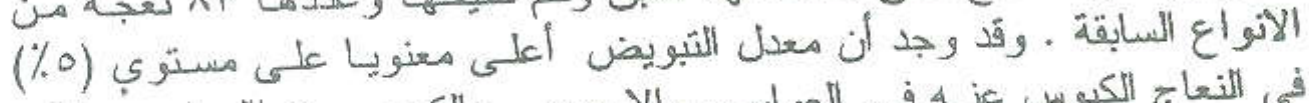

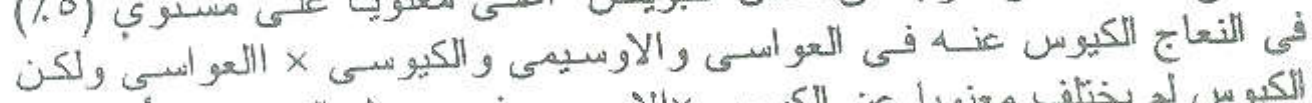

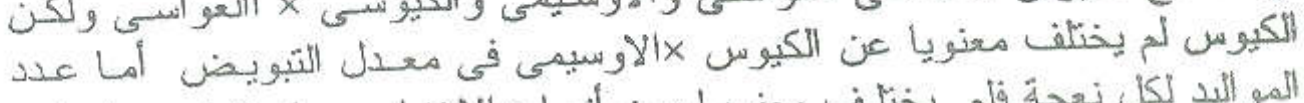

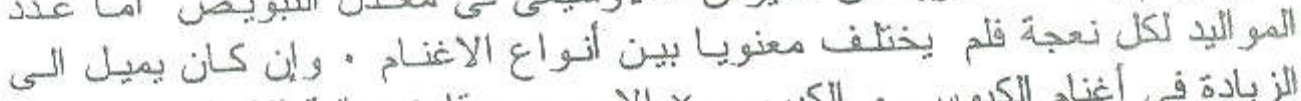

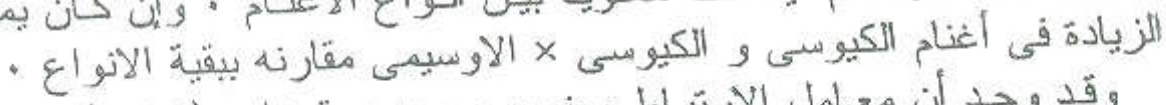

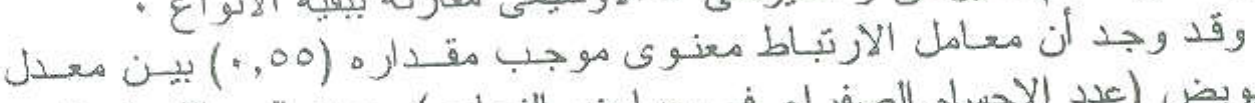

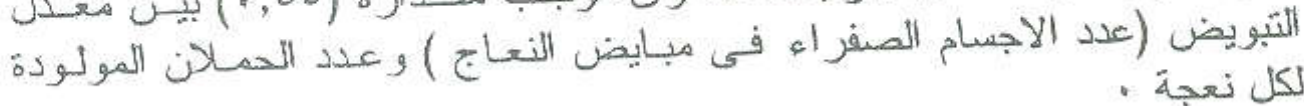

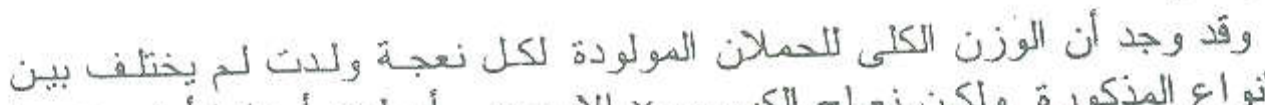

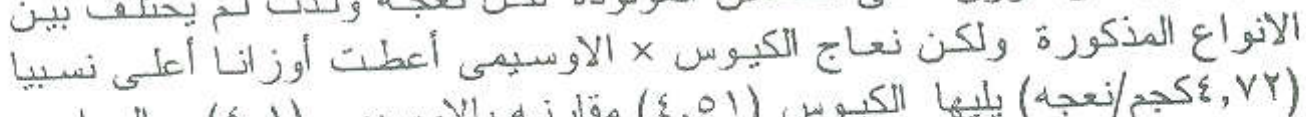

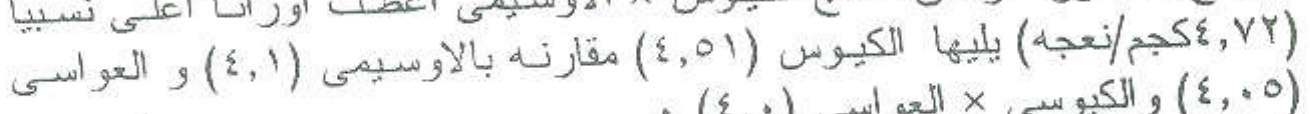

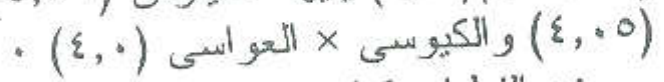

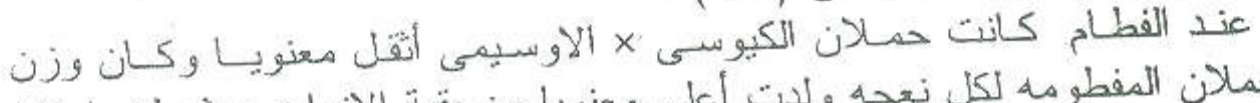

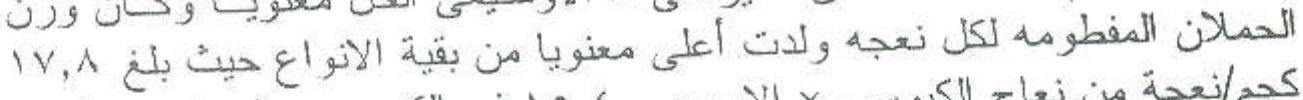

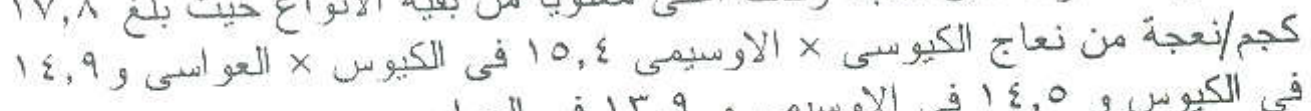

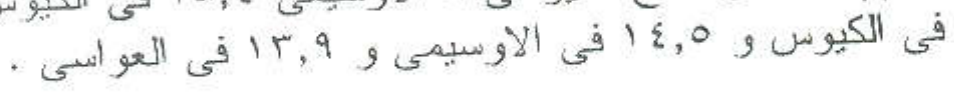

